\title{
FLUVIAL MODULATION OF HYDRODYNAMICS AND SALT TRANSPORT IN A HIGHLY STRATIFIED ESTUARY
}

\author{
Carla de Abreu D'Aquino ${ }^{1}$, Jurandir Pereira Filho ${ }^{2}$ and Carlos Augusto França Schettini, ${ }^{3, *}$
}

${ }^{1}$ Universidade Federal do Rio Grande do Sul - UFRGS

Programa de Pós-Graduação em Geociências - PPGGEO

(Av. Bento Gonçalves, 9500. Bl. 1. Prédio 43113, Campus do Vale Agronomia, 91509-900 POA, RS, Brasil) cadaquino@gmail.com

${ }^{2}$ Universidade do Vale do Itajaí - UNIVALI

Centro de Ciências Tecnológicas da Terra e do Mar-CTTMar

(Rua Uruguai, 458. Bl. 19. Sala 116, 88302-202 Itajaí, SC, Brasil) jurandir@univali.br

${ }^{3}$ Universidade Federal do Ceará - UFC

Instituto de Ciências do Mar - LABOMAR

(Av. da Abolição, 3207, 60165-081 Meireles, Fortaleza, CE, Brasil)

*Corresponding author: guto.schettini@gmail.com

\section{A B S TR A C T}

An oceanographic campaign was conducted in the Araranguá river estuary during the period from May $11^{\text {th }}$ to $13^{\text {th }}$ of 2006 in order to produce a first hydrographic characterization of this system. The campaign was carried out during the spring tide period, and coincidentally after an intense rain event in the region which produced a peak in river discharge. Water level, currents and salinity time series were recorded hourly during a 50-hour period, at a site nearly $7 \mathrm{~km}$ upstream from the estuarine mouth. Two longitudinal distributions of salinity along the estuary were also recorded. The hydrographic data time-series were used to compute the advective salt flux in order to investigate the changes in the transport terms as a function of the change in discharge. The results showed that the estuarine structure was strongly modulated by the river discharge. The drop in water level of about $0.5 \mathrm{~m}$ during the first 24 hours was directly related to the ebb phase of the river flood. The water column was highly stratified throughout the period, therefore the stratification increased during the last 24 hours. The currents were stronger, ebbing and uni-directional at the beginning and became weaker and bidirectional as the water level went down, assuming a tidal pattern. The total salt transport in the first 25 hours was of $-13.6 \mathrm{~kg} \cdot \mathrm{m}^{-1} . \mathrm{s}^{-1}$ (seawards), decreasing to $3 \mathrm{Kg} \cdot \mathrm{m}^{-1} . \mathrm{s}^{-1}$ during the last 25 hours (landwards). It was also noticeable that the $\mathrm{pH}$ in the estuary, recorded together with the salinity, was around 5 , showing that the water quality in the estuary is affected by the coal mining activity in the hydrographic basin.

\section{RESUMO}

Uma campanha oceanográfica foi realizada no estuário do rio Araranguá durante o período de 11 e 13 de maio de 2006, objetivando fazer uma primeira caracterização hidrográfica do sistema. A campanha foi realizada em condição de maré de sizígia, e coincidentemente após um evento de chuvas intensas na região que produziu um pico de descarga fluvial. Séries temporais de nível da água, correntes e salinidade foram registradas durante 50 horas, em um local aproximadamente $7 \mathrm{~km}$ da desembocadura. Dois levantamentos longitudinais de salinidade também foram realizados. Os dados hidrográficos foram utilizados para calcular o fluxo advectivo de sal visando investigar os termos do transporte em função da mudança da descarga fluvial. Os resultados mostram que a estrutura estuarina foi fortemente modulada pela vazão fluvial. O nível da água baixou em torno de $0,5 \mathrm{~m}$ durante as primeiras 25 horas em relação direta com o decaimento da enchente do rio. Embora a coluna de água fosse altamente estratificada durante todo o período, e a estratificação aumentou durante as últimas 25 horas. As correntes foram mais intensas, de vazante e uni-direcionais no início, tornando mais fracas bidirecionais à medida que o nível da água baixou, adquirindo um padrão de maré. O transporte total de sal nas primeiras 25 horas foi de $-13,6 \mathrm{Kg} \cdot \mathrm{m}^{-1} \cdot \mathrm{s}^{-1}$ (sentido do mar), mudando para $3 \mathrm{Kg} \cdot \mathrm{m}^{-1} . \mathrm{s}^{-1}$ nas últimas 25 horas (sentido de terra). Foi também notável que o $\mathrm{pH}$ no estuário, registrado junto com a salinidade, em torno de 5, indicando que a qualidade da água ficou afetada pela atividade de mineração de carvão que ocorre na bacia hidrográfica.

Descriptors: Estuarine circulation; Salt wedge, Flash flood.

Descritores: Circulação estuarina, Cunha salina, Enchente relâmpago. 


\section{INTRODUCTION}

Estuaries are found in all the coastal regions of the globe, under different climatic conditions and within different tidal range regions, assuming a wide range of geomorphologic, oceanographic and sediment characteristics, although sharing common attributes (NICHOLS; BIGGS, 1985). They are defined as semienclosed bodies of coastal water which have free connection with the open sea and within which sea water is measurably diluted by fresh water derived from land drainage (CAMERON; PRITCHARD, 1963). The effects of up-estuary tidal propagation, fresh water discharge, density difference between fluvial and marine waters and local morphology will determine the mixing pattern of salt and fresh water. The resulting salt distribution may be distinguished as (1) vertically homogeneous, (2) partially mixed or (3) highly stratified (DYER, 1997; MIRANDA et al., 2002). Estuaries are, therefore, subject to incessant changes in ebb/flood tides, spring and neap tide periods, variations in fresh water flow, random effects of wind and irregularities in estuarine geometry, all of which may strongly change the estuarine structure.

The highly stratified estuaries are those, among the various types, of which least is known as compared with partially mixed or vertically homogeneous systems (SCHETTINI et al., 2006). Highly stratified estuaries are associated with the lower stretches of river courses in coastal plains and are relatively narrow as compared to other types of estuaries. The lower stretches of the rivers Itajaí-Açú, Tubarão, Araranguá, Itapocú, Tijucas and Mampituba, on the coast of Sta. Catarina, are examples of this type of estuary. The hydrodynamic and transport processes of the Itajaí-Açú estuary have been more intensively studied because of its economic importance (SCHETTINI; CARVALHO, 1998; SCHETTINI, 2002a,b; SCHETTINI; TOLDO, 2006; SCHETTINI et al., 2006); the Itapocu and Tijucas river estuaries have been investigated once (SCHETTINI et al., 1996); and the estuaries of the Tubarão, Araranguá and Mampituba rivers have never ever been investigated at all as regards their hydrodynamics. The lack of knowledge of these systems was the main motivation for the present study.

In order to obtain a first characterization of the estuarine hydrography, an exploratory oceanographic campaign was conducted in the Araranguá river estuary. During this campaign the estuary's characteristics regarding salt distribution, current pattern and water level variations were observed. Coincidentally, the campaign was conducted just after a period of heavy rain, which made it possible to observe the effects of a river discharge peak on the estuarine hydrodynamics and on the advective transport mechanisms responsible for the salt fluxes. The objective of the present paper is to report on this initial assessment of the physical characteristics of the Araranguá river estuary and present a discussion of the effects of the rapid changes in river discharge on the estuarine salt structure. The $\mathrm{pH}$ was also recorded during the experiment. The coal mining activity undertaken in the Araranguá hydrographic basin is an important economic activity with implications for water quality, and this aspect was also discussed.

\section{Study Area}

The Araranguá river basin is located in the southern part of Santa Catarina State, having a total area of $3020 \mathrm{~km}^{2}$ (SANTA CATARINA, 1997). The climate is mesothermal wet with rains regularly distributed throughout the year on a monthly means basis, although the precipitation rate is highly varied on a daily basis. The annual precipitation and potential

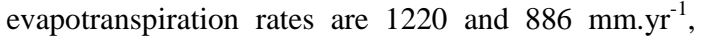
respectively. The average temperature is $19^{\circ} \mathrm{C}$, ranging from 14 to $23^{\circ} \mathrm{C}$ (GAPLAN, 1986).

Most of the river springs are located in Serra Geral, and about 15 main streams compose the drainage system (KREBES, 2004). The Araranguá River is formed by the confluence of the Itoupavas and Mãe Luzia rivers (Fig. 1), having an extension of roughly $35 \mathrm{~km}$ before flowing into the sea. It flows from east to west, with meandering morphology. The lower course $(\sim 7 \mathrm{~km})$ changes to a northeasterly direction, parallel to the coast line, where the inlet is located crossing a dune field. The shore is particularly dynamic, presenting a moderate to strong northerly drift (SIEGLE; ASP, 2007).

The fluvial discharge is monitored on a daily basis at several fluviometric stations by the Brazilian National Water Agency (ANA) distributed throughout the drainage basin. The lowermost stations with no tidal effect on the main tributaries are: Taquaruçu Station (\#84950000; ANA), on the Itoupavas River, and Forquilhinha Station (\#84820000; ANA) on the Mãe Luzia River, with catchment areas of 898 and 523 $\mathrm{km}^{2}$, respectively (30 and $18 \%$ of the total drainage, respectively). The historical (1943 to 2004) mean discharge for Taquarucu Station is $42.2 \pm 73.2 \mathrm{~m}^{3} . \mathrm{s}^{-1}$, with a maximum of $847 \mathrm{~m}^{3} \cdot \mathrm{s}^{-1}$. The Forquilhinha Station's historical (1942 and 2004) mean discharge is of $23.5 \pm 51.4 \mathrm{~m}^{3} \cdot \mathrm{s}^{-1}$, with a maximum of $1103 \mathrm{~m}^{3} \cdot \mathrm{s}^{-1}$. The historical mean discharge for the month of May, when the field campaign was conducted, is $11.1 \pm 12.2$ $\mathrm{m}^{3} \cdot \mathrm{s}^{-1}$ and $22.5 \pm 21.9 \mathrm{~m}^{3} \cdot \mathrm{s}^{-1}$ for the Forquilhinha and Taquaruçu Stations, respectively. 


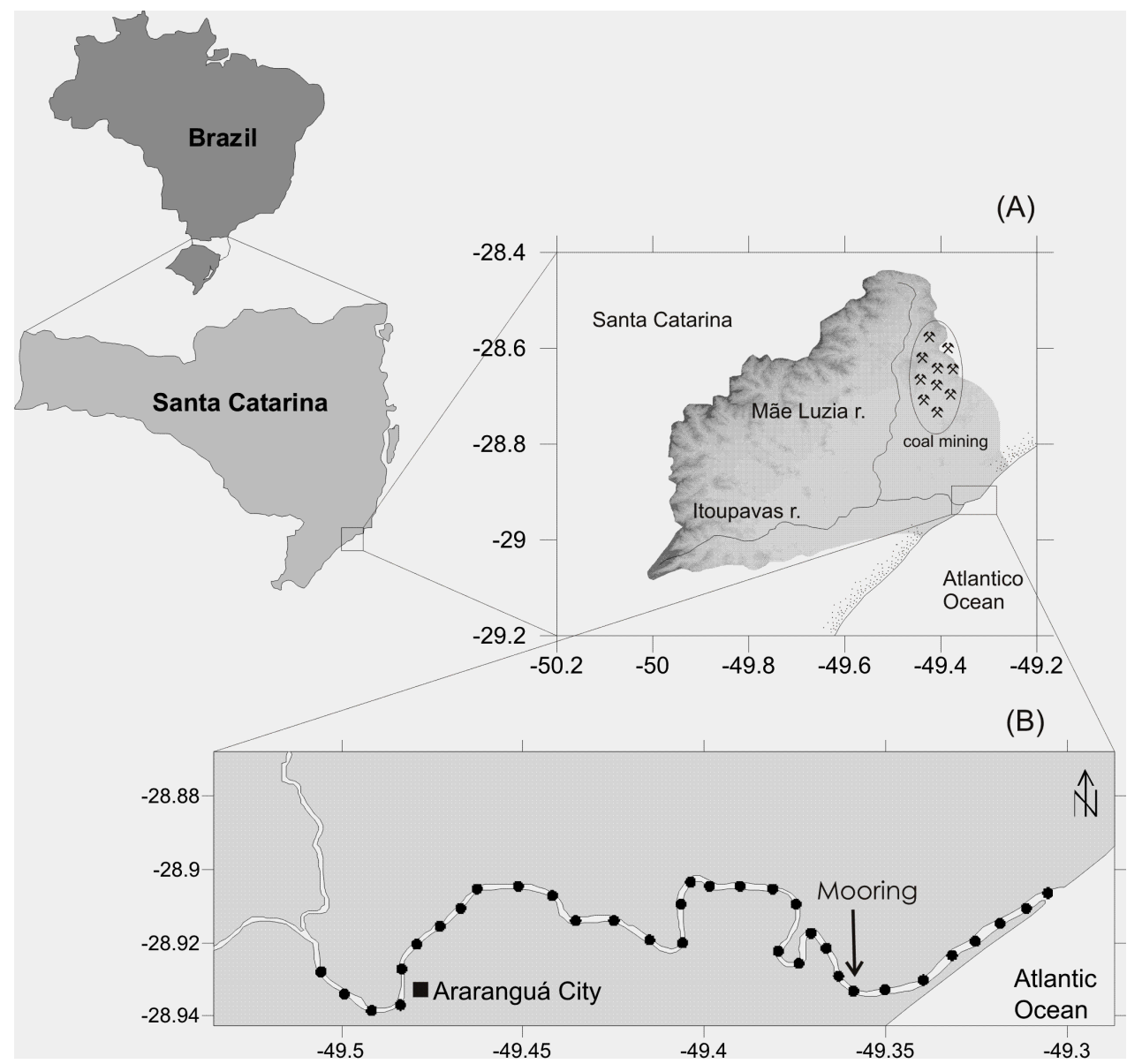

Fig. 1. Araranguá river basin (A) with the two main streams (Itoupava r. and Mâe Luzia r.). Estuarine stretch (B) with indication of the sampling stations and mooring position.

The historical records of river discharge present large temporal variability with a poor seasonal pattern, which is in accord with the climatic characteristics of the region. According to Krebs (2004), the cold fronts that cross the Santa Catarina State throughout the year generate climatic instability and the high precipitation rate right through the year. The localization of the drainage basin and its morphology determine the rain patterns and distribution, resulting in short time of concentration of the hydrogram which produce flash flood events. The variation in topography within the catchment area, the greatest heights being the Serra Geral scarp peaks $(1400 \mathrm{~m})$, produces both orographic and convective rainfall, which affects the spatial distribution of the precipitation.

The main economic activities of the region are agriculture (mainly rice production), cattle breeding and the mining and processing of coal. Studies addressing water utilization and pollution issues have been conducted in the region (ANDRADE, 1989; GOTHE, 1989; VILLELA, 1989; ALTHOFF, 1990; GAIDIZINSKI, 2001; SCHEIBE，2002) and have shown that both agricultural and coal mining activities produce pollutants at levels that cause negative effects. Pyrite oxidation is one of the main processes associated with coal mining. When exposed to air and rain, the pyrite oxidizes, generating sulfuric acid and iron compounds, thus acidifying the water. The Araranguá River is affected by this process, mainly by the water from the Mãe Luzia River, the $\mathrm{pH}$ levels of which can sink below 3.5 (GOTHE, 1993).

The rice culture affects the nutrient budgets, although the main concern relates to water utilization. Estimates published by EPAGRI (1998) have shown that the water demand of the rice crops in the region can be up to six times the averaged fluvial discharge. This can affect the water supply for human consumption and also increases the salt intrusion into the estuarine stretch. It is empirically known by water 
users that salinity is observed up to $35 \mathrm{~km}$ upestuary, reaching the Itoupavas and Mãe Luzia rivers.

The local coast is wave dominated, having a microtidal regime. Wintertime waves are more energetic, being associated with the cold fronts (ARAÚJO et al., 2003). Tidal records from Mampituba estuary, $60 \mathrm{~km}$ to the south of Araranguá inlet, present a tidal range of from 0.2 to $0.6 \mathrm{~m}$ during neap and spring tides, respectively. The tidal form number, defined as the ration between main diurnal and semi-diurnal components of tide= $\left[\mathrm{O}_{1}+\mathrm{K}_{1}\right] /\left[\mathrm{M}_{2}+\mathrm{S}_{2}\right]$ (e.g. PUGH, 1987), is 1.3 which means a mixed type. The influence of the meteorological tides may be expected to be at least as important as it is on the northern coast of Santa Catarina (TRUCCOLO et al., 2006) considering that the tidal range is smaller.

The offshore water salinity and temperature have been investigated in terms of meso-scale shelf processes (MIRANDA, 1972; MOLLER et al., 2008; HILLE et al., 2008). The region is dominated by Coastal Water (CW) and South Atlantic Coastal Water (SACW). The $\mathrm{CW}$ is associated with the local fresh water contribution and with the Plata River Plume on a larger scale, mainly during the winter. The SACW occurs mainly during the summer in association with the upwelling that occurs around Santa Marta Cape (PEREIRA et al., 2009).

\section{Material and Methods}

\section{Field Survey}

The field campaign was conducted at 11 to 13 May 2006, during a period of spring tide. The campaign coincided with the waning phase of a flash flood event (Fig. 2). Bathymetric data, bottom samples, time series of water level, currents, salinity, and $\mathrm{pH}$, and spatial distribution of salinity and temperature were acquired.

Bathymetric data was recorded with an echosounder L4100 by Furuno ${ }^{\mathrm{TM}}$, and the position with a GPS receiver XL12 by Garmin ${ }^{\mathrm{TM}}$. The surveyed stretch comprised since the estuarine mouth until the Araranguá city, nearly $27 \mathrm{~km}$ up-estuary. The bathymetric data was reduced to a base level referenced by the lower level measured by the moored instruments in the lower estuary (cf. below).

Water level, currents, salinity and $\mathrm{pH}$ time series were acquired with moored instruments in the lower estuary, nearly at $7.5 \mathrm{~km}$ upstream from the mouth (28 $55^{\prime} 40.6^{\prime \prime}$ ' \& 49 $21^{\prime} 33.2^{\prime \prime}$ 'W Fig. 1A), in the cross section thalweg at $8.5 \mathrm{~m}$ deep. This position was chosen based on presence of a nautical facility there. Water level and current speed and direction were recorded with an Acoustic Doppler Current Profiler (ADCP) Aquadopp Profiler ${ }^{\circledR}$ by Nortek ${ }^{\mathrm{TM}}$, of
$1000 \mathrm{kHz}$. The ADCP was setup to record data at 10minutes intervals, averaging 120 seconds at a $2 \mathrm{~Hz}$ sampling rate, with $0.3 \mathrm{~m}$ of cell size (e.g. the vertical resolution). For convention, down estuary current directions were assigned negative, and up estuary positive.

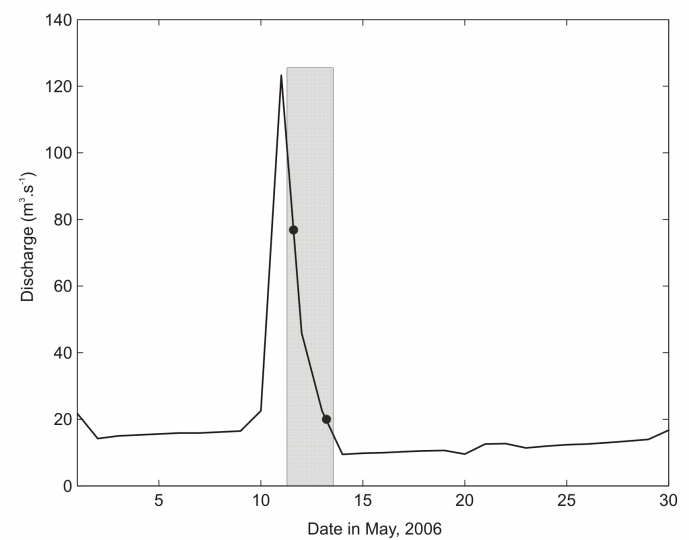

Fig. 2. Hydrography of the Itoupava r. for the month of May, 2006. The hachured part represents the campaign period and the points mark when the longitudinal surveys were carried out.

Salinity and temperature were recorded at 1 $\mathrm{m}$ above de bed (bottom) and nearly $1 \mathrm{~m}$ below the surface. The bottom data was recorded with a CTD probe SD-204 by Saiv ${ }^{\mathrm{TM}}$, which also recorded turbidity through an optical back scatter SeaPoint ${ }^{\mathrm{TM}}$ sensor. The surface data was recorded with a multiparameter probe 6600 by $\mathrm{YSI}^{\mathrm{TM}}$, sampling at 5-minute intervals. The multi-parameter probe, besides salinity and temperature, also recorded $\mathrm{pH}$, dissolved oxygen and chlorophyll-a. Therefore, only the $\mathrm{pH}$ data will be described and discussed. The data acquisition from the mooring lasted for 50 hours, from 11 to 13 May.

Two surveys along the estuary were carried out at 11 and 13 May to acquire salinity and temperature data. The surveys were performed with a speed boat allowing it to be concluded in less than 2 hours, furnishing a quasi-synoptic picture of the estuarine structure. The vertical profiles of salinity and temperature were recorded every $1 \mathrm{~km}$ from the estuarine mouth until the city of Araranguá using a CTD probe SD-204 by Saiv ${ }^{\mathrm{TM}}$ (Fig. 1B).

Complementary data of precipitation and river discharge were obtained with the Center of Environmental Resources and Hydrometeorology Information of Santa Catarina State (CIRAM/EPAGRI).

Decomposition of Advective Salt Transport

The decomposition of the advective transport of salt has been applied to assess the 
modification of the estuarine dynamics during the recession of the flood peak. Decomposition is a tool used to evaluate the main mechanism acting in the estuarine transport (MEDEIROS; KJERFVE, 2005). The decomposition scheme applied was described by Miranda et al. (2002), based on Bowden (1963), Fisher (1976), Hunkins (1981), Dyer (1974) and Kjerfve (1986). Considering a laterally homogeneous estuarine cross section, the longitudinal velocity component $u$ can be decomposed as

$u(x, z, t)=u_{a}(x)+u_{t}(x, t)+u_{s}(x, z)+u^{\prime}(x, z, t)$

where $u_{a}$ is the time and depth-averaged value, given by $\langle\bar{u}\rangle$. The depth-average operation is designated by the over bar, and the time-average operation is designed by the brackets, which must be averaged over one or more complete tidal cycles. The $u_{t}$ term represents the variation of the instantaneous depthaveraged velocity along the tidal cycle related to $u_{a}$, given by $u_{t}=\bar{u}-u_{a}$. The $u_{t}$ term was considering the bottom and surface levels at the same level of salinity were collected. The $u_{s}$ term represents the variation of the time-averaged velocity along the water column, given by $u_{s}=<u>-u_{a}$. The $u$ ' term represents the residuals, which can be attributed to small-scale physical processes, given by $u^{\prime}=u-u_{a}-u_{t}-u_{s}$. Similar decomposition can be applied to the salinity. The total water depth $h$ also varies with the tide, and can also be decomposed by its variation along the tidal cycle as

$h(x, t)=h_{a}+h_{t}(x, t)$

where $h_{a}$ is the time-averaged water depth, given by $\langle h\rangle$, and $h_{t}$ is the water level variation along the tidal cycle. The averaged salt transport for one or more tidal cycles $T_{S}$ is given by

$T_{S}=\frac{1}{T} \int_{0}^{T} \int_{0}^{h} \rho u S d z d t$

where $\rho$ is the water density and $S$ is the salinity. The substitution of Eq. 1 is similar for salinity in the Eq. 3 producing 32 terms in which only 7 have physical significance and are non-zeros. Thus, the total average salt transport for one or more tidal cycles can be written as

$$
\begin{aligned}
& T_{S}=\bar{\rho}\left(u_{a} h_{a} S_{a}+<h_{t} u_{t}>S_{a}+h_{a}<u_{t} S_{t}>+h_{a} \overline{u_{s} S_{s}}+\ldots\right. \\
& \left.\ldots+h_{a}<\overline{u^{\prime} S^{\prime}}>+<u_{t} S_{t} h_{t}>+u_{a}<S_{t} h_{t}>\right)
\end{aligned}
$$

where according to Miranda et al., (2002), the seven terms inside the parenthesis can be attributed to (A) fluvial discharge, (B) Stokes drift, (C) tidal correlation, (D) gravitational circulation, (E) tidal pumping, (F) tidal shear, and $(\mathrm{G})$ wind fluctuation. The seventh term may also be attributed to supra tidal effects, either wind fluctuation or changing river discharge. The decomposition was performed using a 25 -hour window running over the 10 minute data, what 128 sets of transport terms.

\section{RESULTS}

The mean estuarine depth was of $7.2 \mathrm{~m}$ along the $27 \mathrm{~km}$ between its mouth and the town of Araranguá. The river has a well defined channel throughout this part without islands, shallows or intertidal flats. The estuary is shallower along the lower $10 \mathrm{~km}$ stretch, with mean depth of about $5 \mathrm{~m}$. The depth increased up-estuary to around $9 \mathrm{~m}$, with variation of more or less $2 \mathrm{~m}$. The mean estuarine breath was about $170 \mathrm{~m}$ near the mouth, decreasing upstream, and being of about $80 \mathrm{~m}$ at the town of Araranguá.

The campaign was carried out just after an intense rain shower event that lasted for three days. The accumulated rainfall in the period of 9 to 11 May was of the order of $80 \mathrm{~mm}$. In terms of comparison, the long term mean precipitation rate for May is of 83 $\mathrm{mm}$ (source: http://www.ana.gov.br). The resulting river discharge was of $123 \mathrm{~m}^{3} \cdot \mathrm{s}^{-1}$, at 11 May, waning to 45 and $25 \mathrm{~m}^{3} \cdot \mathrm{s}^{-1}$ in the following days (Fig. 2).

The maximum water level was recorded in the beginning of the experiment, decreasing rapidly during the first hours (Fig. 3B). The water level down $0.8 \mathrm{~m}$ during the first 6 hours, and varied of $0.4 \mathrm{~m}$ in the next 6 hours. During the rest of the experiment the water level variation was of $0.2 \mathrm{~m}$ and presented a tidal pattern. The tidal signal in the water level was asymmetric, with the flood lasting three to four hours, while the ebb lasting approximately 8 hours.

The currents in the beginning of the experiment were stronger and uni-directional downestuary (ebbing), reaching $-0.4 \mathrm{~m} . \mathrm{s}^{-1}$ (Fig. 3A). This flow regime lasted for the next 8 hours, although less intense, until the next flood when upstream currents of $0.2 \mathrm{~m} . \mathrm{s}^{-1}$ were observed. From this moment on, during the ebbing tidal phase, gravitational circulation was established in the estuary with down-estuary currents in the top layer and up-estuary in the lower layer during ebb tidal phase.

The salinity time series showed strong stratification during the whole sampling period (Fig. $3 \mathrm{C})$. In the beginning of the experiment the surface salinity was of about 10 and down to zero as time went by. The near bottom salinity was around 28 in the beginning of the experiment. Within 6 hours of campaign the salinity decreased to 10 , right after the tide inflow. The bottom salinity increased again at the 
slack-tide period and slowly decreased again during the ebb tide period, ranging from 22 to 9 . Within 18 hours of experiment, a new flood occurred and the salinity values varied between 10 and 12 . During the following ebb, salinity increased to 22 and remained at this value until the end of experiment.

The $\mathrm{pH}$ during the entire sampling period ranged between 4.4 and 5.7 (Fig. 3D). The $\mathrm{pH}$ presented a direct relationship with salinity, when the higher values were observed at the beginning of the campaign when the surface salinity was 10 and $\mathrm{pH}$ 5.7. The $\mathrm{pH}$ decreased as the water level and salinity did. When the salinity become smaller than 3 , the largest $\mathrm{pH}$ variation was observed, with the $\mathrm{pH}$ values decreasing from 5.4 to 4.7. At the end of the experiment the surface salinity increased to 1 , and there was also a response of the $\mathrm{pH}$, which raised a little. These results indicated a strong relationship between the $\mathrm{pH}$ and the freshwater content in the estuary.

The turbidity near bottom was low during the first 24 hours of the experiment, below 10 FTU. There was a steep increase at the $24^{\text {th }}$ hour, reaching 190 FTU (Fig. 3E). The turbidity peak lasted for nearly three hours, and decreased and stabilized at approximately $30 \mathrm{FTU}$ until the end of the experiment. The turbidity peak was synoptic to the first period of flooding currents.
(A)

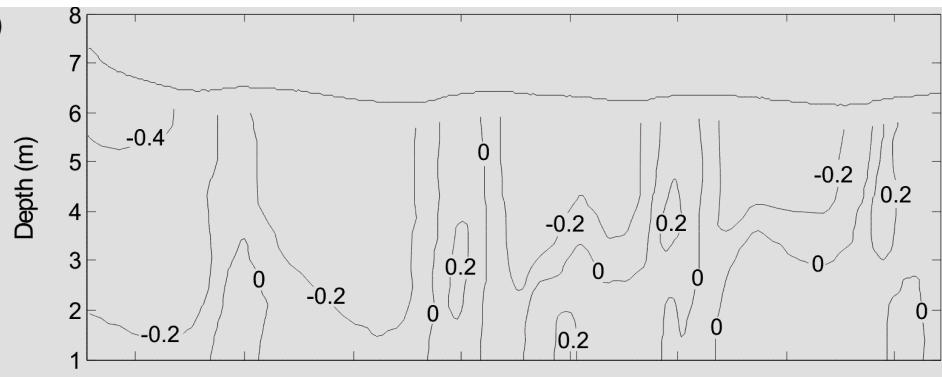

(B)

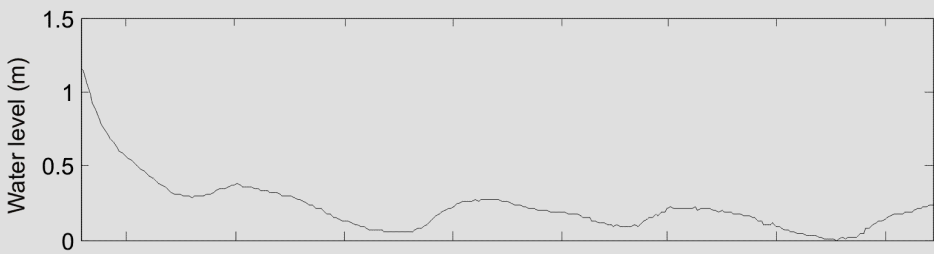

(C)

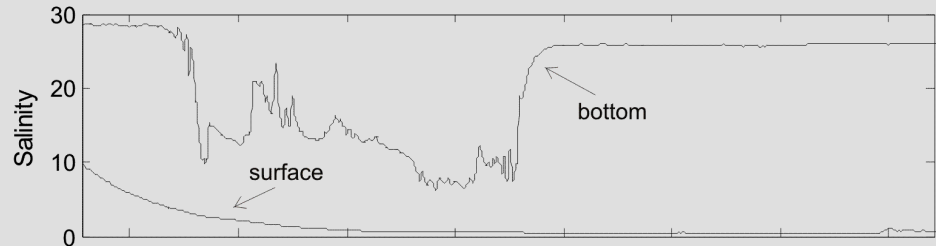

(D)

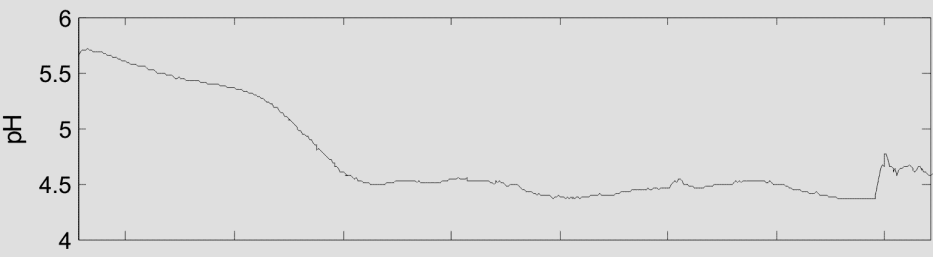

(E)

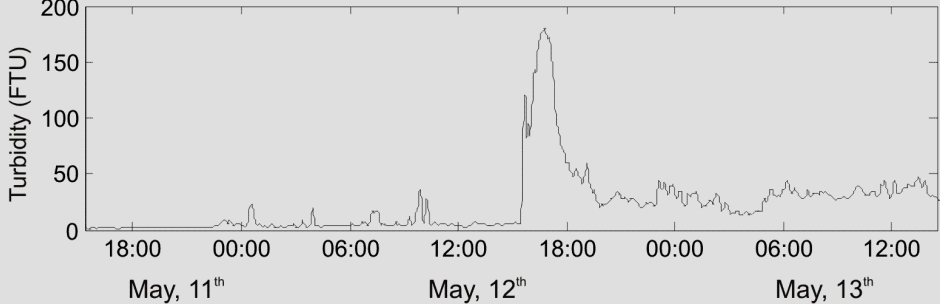

Fig. 3. Temporal variation of the oceanographic data collected at the mooring position during the campaign; (A) vertical and temporal current velocity (+: flood; -:ebb, in $\mathrm{ms}^{-1}$ ); (B) water level (m); (C) surface and nearbottom salinity; (D) surface $\mathrm{pH}$ and (E) near bottom turbidity (NTU). 
Figure 4 presents the salinity distributions along the Araranguá river estuary during 11 and 13 May. At the 11 May the salt presence was observed until $22 \mathrm{~km}$ from the river mouth, and at 13 May, the salinity was observed up to $11 \mathrm{~km}$. The maximum value of salinity in the first survey was 16 and the isohalines were tilted, meanwhile during the second survey the maximum salinity was of 32 and the isohalines were nearly horizontal, indicating higher stratification.

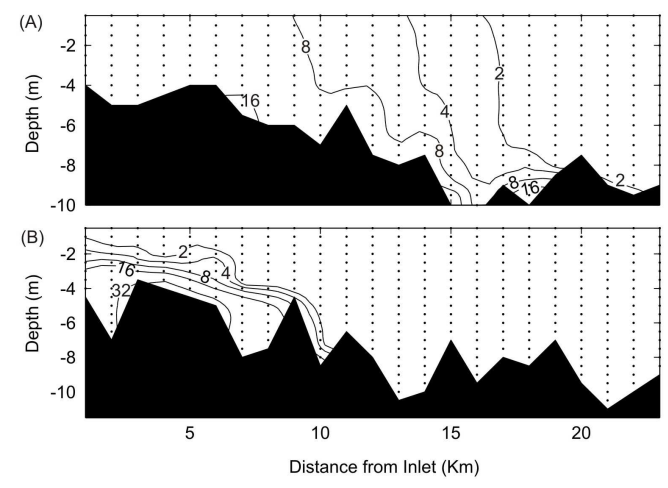

Fig. 4. Longitudinal salinity distribution at (A) May, $11^{\text {th }}$ and (B) May, $13^{\text {th }}$.

The time-averaged surface and near bottom current velocities were -0.27 and $-0.15 \mathrm{~m} . \mathrm{s}^{-1}$, respectively, and salinity were 1.2 and 15.1, respectively, for the first period of 25 -hours. For the later 25-hour period the values of current velocities were -0.16 and $0.03 \mathrm{~m} . \mathrm{s}^{-1}$, at surface and near bottom, respectively, and salinity were 1 and 13.2 at the same order. The salt transport mechanisms for the first and last 25-hours periods of the experiment, representing the two distinct conditions described above, are presented in Table 1. During the first period, the total salt transport was $-9.1 \mathrm{Kg} \cdot \mathrm{m}^{-1} \cdot \mathrm{s}^{-1}$ (out of estuary), and during the second period, the total salt transport was of $0.8 \mathrm{Kg} \cdot \mathrm{m}^{-1} \cdot \mathrm{s}^{-1}$ (into the estuary). The fluvial discharge mechanism decreased by half from the first period to the second. The tidal correlation, usually a dispersive up-estuary mechanism, was down-estuary during the first period. The gravitational circulation salt transport increased by $2.5 \mathrm{x}$. The other mechanisms did not present significant values.

\section{DisCUSSION}

The oceanographic campaign conducted in the Araranguá river estuary had an exploratory character, featuring the first survey on the physical processes of this system. However, taking into account the hydrological conditions during the campaign, it was possible to investigate the effects of the fluvial discharge on the estuarine hydrodynamics. The rainfall that preceded the measurements produced a flashflood event and the wave of discharge affected the water level, currents, salinity and the $\mathrm{pH}$.

Table 1. Salt transport terms calculated for the first and last 25-hour periods of experiment, with comparative results from the Itajaí-Açu Estuary (SCHETTINI et al., 2006). Values in $\mathrm{kg} \cdot \mathrm{m}^{-1} \cdot \mathrm{s}^{-1}$.

\begin{tabular}{lccc}
\hline \hline TERMS & FIRST 25 h & LAST 25 h & Itajaí-Açu \\
\hline Fluvial discharge & $\mathbf{- 1 1 . 2}$ & $\mathbf{- 3 . 3}$ & $\mathbf{- 1 0 . 3}$ \\
Stokes drift & -0.1 & 0.0 & $\mathbf{2 . 1}$ \\
Tidal correlation & $\mathbf{- 0 . 5}$ & 0.0 & $\mathbf{5 . 3}$ \\
$\begin{array}{l}\text { Gravitational } \\
\text { circulation }\end{array}$ & $\mathbf{2 . 6}$ & $\mathbf{3 . 8}$ & $\mathbf{1 6 . 3}$ \\
Tidal pumping & 0.0 & -0.0 & $\mathbf{2 . 9}$ \\
Tidal shear & -0.0 & 0.0 & 0.0 \\
Wind fluctuation & -0.2 & -0.0 & -0.1 \\
Sum & -9.1 & 0.7 & 16.2 \\
Transport (Eq. 3) & -9.1 & 0.8 & 16.3 \\
\hline
\end{tabular}

The flow rate provides by simple means the relative importance between the tidal forcing and fluvial discharge, and can be used here to scale the changes observed during the experiment. The flow rate is calculated by the ratio between the integrated fluvial discharges for a tidal cycle period (12.4 hours) to the tidal prism volume. The latter is calculated by the product of the tidal height to the estuarine surface area (DYER, 1997). Considering the historical average discharge for May, $22 \mathrm{~m}^{3} \cdot \mathrm{s}^{-1}$, the estuarine area, of approximately $3.7 \mathrm{~km}^{2}$, and the mean tidal range of $0.26 \mathrm{~m}$, the flow ratio is 1.1 . What means that the river discharge volume contribution is equivalent to the tidal prism, and the estuary is highly stratified on averaged basis (DYER, 1997). The flow ratio during the first 25 -hours period was 5 , reducing to 1 in the latter period, changing in 5-times fold.

The current and salinity time-series at surface and near-bottom permit to classify the estuary based on non-dimensional circulation and stratification parameters (HANSEN; RATTRAY, 1966). The stratification parameter is calculated by the ratio of the difference between the bottom and surface salinity to the depth averaged salinity. The circulation parameter is calculated by the ratio of the surface current velocity to the depth averaged current velocity (MIRANDA et al., 2002). The data averaged over the whole data set ( $\sim 50$ hours; $\sim 4$ semi-diurnal tidal cycles) resulted in circulation and stratification parameters of 1.8 and 2.5, respectively, what means type 4 , salt wedge estuarine structure (e.g. DYER, 1997; MIRANDA et al., 2002). This reinforces the flow ratio indication of a fluvial dominated regime. 
The salinity distribution in a given estuary is a balance between diffusion and advection (DYER, 1974). The salt content is an indicator of the mixing between fresh and marine waters, and its flux and transport can be used to infer the main physical mechanisms responsible for the transport of other scalars (MIRANDA; CASTRO-FILHO, 1996). The salinity distribution along the estuary presented a pattern that disagrees with the discharges condition: the degree of stratification increased as the river discharge decreased (Fig. 5). This result was interpreted as a response delay of the salinity structure to the flash flood event. During the period of about a month before the survey did not rain in the drainage and the river discharge was below the averaged values. Thus, tidal effects producing vertical mixing would prevail on the fluvial advection, reducing the stratification.

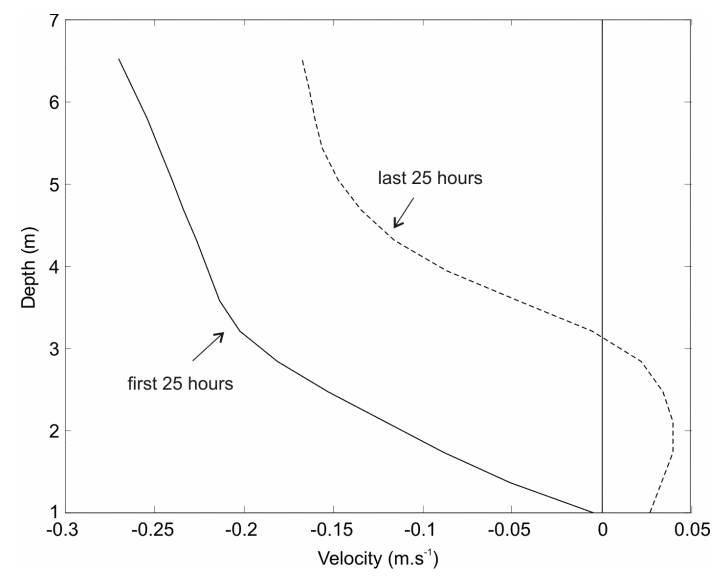

Fig. 5. Time-averaged current velocity profiles for 2 tide cycles for the first and last 25-hour periods.

The Araranguá estuary shares common climatic, tidal and morphologic characteristics with the Itajaí-açu estuary, $300 \mathrm{~km}$ north. The latter has been more intensively studied, making it as a model for comparisons. The fine sediments transport regime in the Itajaí-açu estuary is defined as flash-flood dominated (SCHETTINI; TOLDO-JR., 2006), presenting two main transport modes: a marine and a fluvial. The marine mode occurs during low discharge periods where the transport processes are controlled by tides; the riverine suspended particulate matter (SPM) inflow is reduced and mostly trapped in the estuary. The fluvial mode operates when the river discharge is above the average; the riverine SPM concentration increase; and the trapping decreases to zero. It is hypothesized that the Araranguá estuary behaviors like the Itajaí-Açu. What was observed in the Araranguá river estuary was a transitional condition during the evolution of a discharge flood passage, what was never related for the Itajaí-açu estuary.

The time variation of salinity presented a complex pattern. The rapid decrease of bottom salinity in the beginning of the experiment could be first though of as being associated with advection of fresh bottom waters from upstream, however it happened when the bottom currents were up estuary during tidal floods. This phenomenon was observed during the $8^{\text {th }}$ and $20^{\text {th }}$ hours of experiment Figure ( $3 \mathrm{~B}$ and $\mathrm{C}$ ). This characteristic is probably due to water advection from lower estuary. From the mooring site towards the mouth, the estuary becomes wider and shallower $(<5$ $\mathrm{m}$ ) extending for $7.5 \mathrm{~km}$ before it debouches to the sea. Thus, vertical mixing caused by tides and/or tides in this stretch of the estuary would be more effective. The tidal excursion derived from the current measurements was of the order of $5 \mathrm{~km}$, which means that a flooding water parcel that passes through the mooring site is originated from the lower estuarine basin instead coastal waters, being a mixture of river inflow from the recent river flood, and older brackish estuarine waters. During the next tide period the water volume was completely exchanged and the inflow of coastal waters was observed near the bottom, indicated by the higher salinity. The turbidity time series corroborated this hypothesis. Initial estuarine waters were less turbid, and when the advection of coastal waters effectively took place, it came with a front of turbidity moving up estuary.

Dyer (1977), assessing the salt transport in salt wedge, partially mixed and well mixed estuaries concluded that in the first ones the gravitational circulation was the main mechanism of transport up estuary. This was also verified in the present case, mainly in the last 25-hour period of the experiment. During the first 25 hours of the experiment the fluvial discharge overcome the gravitational circulation, with residual salt transport down estuary (Table 1). The negative salt transport in the first 25 -hour period indicates the water volume replacement in the estuarine basin with new fresh water. During the second 25-hour period, buoyancy flux starts to take place generating the observed gravitational circulation indicated by the currents pattern. These effects are well demonstrated by the time-averaged vertical current profile (Fig. 5). During the first period the residual current vertical profile is down estuary along the depth, while it becomes more 'estuarine-likeexpected' during the second period, with direction inversion: down estuary at the top, and up estuary at the bottom layer.

The river discharge modulation of the salt transport terms is clearly observed by the evolution of fluvial discharge and gravitational circulation salt transport terms (Fig. 6). The gravitational circulation 
is presented in module to improve the visualization. The staircase pattern along the time series is probably caused by oscillations of the river discharge during the period. Therefore, the rate of change of fluvial discharge term down is much higher than the rate of change of gravitational circulation up. This result can be understood by the dilution of the water of the lower stretch of the estuary, which started to be advected up estuary by the tidal effect. Thus, the inflowing water was not new salty coastal waters rather brackish ones still strongly affected by the flash flood event. It is expected that the evolution of the scenario is the stabilization of the river discharge term, and the increase of the dispersive up-estuary terms, mainly of the gravitational circulation and the tidal correlation ones. This is suggested by the salt transport terms of Itajaí-Açu estuary, where they were calculated based on a 25 -hour observation at spring tide and low river discharge condition (SCHETTINI et al., 2006; Table $1)$.

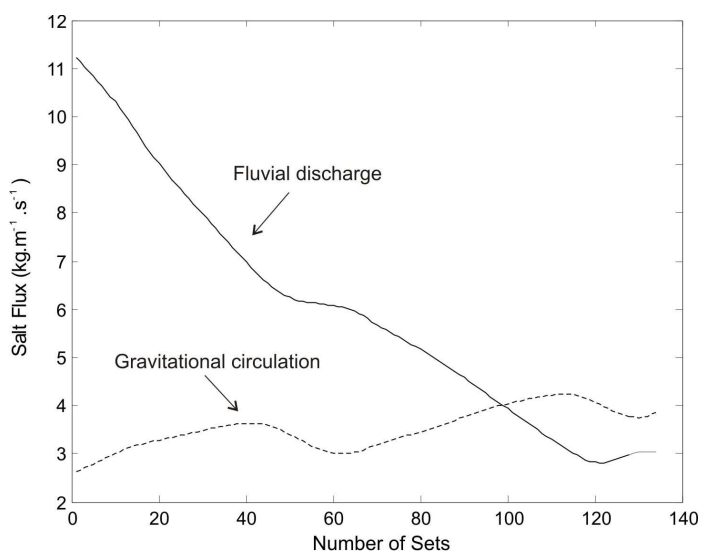

Fig. 6. Temporal variation of Fluvial Discharge (in module) and Gravitational Circulation terms of advective salt transport (in $\mathrm{Kg} \cdot \mathrm{m}^{-1} \cdot \mathrm{s}^{-1}$ )

The tidal correlation term is a tide related dispersive term, which transport salt up estuary (MIRANDA; CASTRO- FILHO, 1996; Miranda et al., 2002). The negative value found for the first 25 -hour period was unexpected, at least if interpreted by means of tide modulation of water level only. This term is calculated by the triple correlation between depth averaged current, water depth and salinity. Its negative value for the first 25 -hour period was attributed to the water level modulation by the flash flood and unidirectional ebb currents. The Figure 7 presents the water level / velocity diagram for the both 25 -hour periods, where the non-tidal flash flood pattern is a vertical line indicating the waning phase of the flood wave.

\section{Acid Waters}

The $\mathrm{pH}$ presented values significantly low when compared with other regional estuarine systems (SCHETTINI et al., 2000; RÖRIG et al., 2007), and was firstly attributed to the coal mining activity at the Araranguá river basin. A consequence of coal mining activity is the acid drainage, and the Araranguá drainage basin encompasses one of the major coal mining regions of Brazil. Values of $\mathrm{pH}$ below 3 have been reported for small streams in the Araranguá drainage basin (GOTHE, 1989). The acidification occurs when the pyrite of abandoned mines or dumping sites is exposed to air and water generating sulfuric acid and dissolving iron. The iron can then be totally or partially precipitated forming red, orange or yellow sediment at the bottom of waterways (WHITE et al., 1997). The oxidation reactions involve the dissolution of solid pyrite into iron and sulphate according the equation (5):

$\mathrm{FeS}_{2(\mathrm{~s})}+7 / 2 \mathrm{O}_{2}+\mathrm{H}_{2} \mathrm{O} \longrightarrow \mathrm{Fe}^{2+}+2 \mathrm{SO}_{4}{ }^{2-}+2 \mathrm{H}^{+}$

The iron II produced in the equation 5 will oxidize into iron III that is hydrolyzed with more liberation of more acid according the equations 6 and $7:$

$\mathrm{Fe}^{2+}+1 / 4 \mathrm{O}_{2}+2 \mathrm{H}^{+} \longrightarrow \mathrm{Fe}^{3+}+\mathrm{H}_{2} \mathrm{O}$

$\mathrm{Fe}^{3+}+3 \mathrm{H}_{2} \mathrm{O} \longrightarrow \mathrm{Fe}(\mathrm{OH})_{3(\mathrm{~s})}+3 \mathrm{H}^{+}$

If the $\mathrm{pH}$ of the environment is less than 4 iron III remains in solution and can oxidize pyrite directly (Equation 8) resulting in more acid production and starting a cyclical reaction involving iron II and III with strong environment acidification.

$\mathrm{FeS}_{2}+14 \mathrm{Fe}^{3+}+8 \mathrm{H}_{2} \mathrm{O} \longrightarrow 15 \mathrm{Fe}^{2+}+2 \mathrm{SO}_{4}{ }^{2-}+16 \mathrm{H}^{+}$

At $\mathrm{pH}$ above 4 , the iron III precipitates as iron hydroxide or iron-hidride $(\mathrm{FeOOH})$, resulting in the formation of red flocs (WHITE et al., 1997).

The Araranguá estuarine waters were acid even with marine waters influence. The highest $\mathrm{pH}$ values were observed in the beginning of the experiment, associated with the higher salinity. The $\mathrm{pH}$ decreased during de monitored period and only showed a small increasing in response to a small increasing in the salinity at the end of experiment (Fig. $3 \mathrm{E})$. The temporal variation of $\mathrm{pH}$ reflects the influence of the buffer effect of the sea water. This behavior was already observed in other estuaries 
subjected to the influence of acid drainage from mining activities. In the cases of Ria del Tinto and Ria del Odiel, in Spain, the $\mathrm{pH}$ above 4 is observed for salinity higher than 20 (BRAUNGARD et al., 2003).

An implication of the low $\mathrm{pH}$ in estuarine waters is the facilitation of the exportation of metal pollutants: the low $\mathrm{pH}$ keep them dissolved instead adsorbed to fine sediments (ACHTERBERG et al., 2003). Furthermore, low pH works as a flocculation agent and would play as a factor to removal suspended sediment from water column. This explains the low turbidity recorded. The highly stratified estuarine structure observed indicates the dominance of advection transport processes, and small mixing between river and marine waters. Dyer (1995) suggests that such condition favors the riverine materials transfer to the inner shelf, and low trapping efficiency. Thus, it is expected that the Araranguá estuary is an exporter of dissolved contaminants to the coastal sea under moderated and high river discharge, therefore it may be and efficient fine sediment trap.

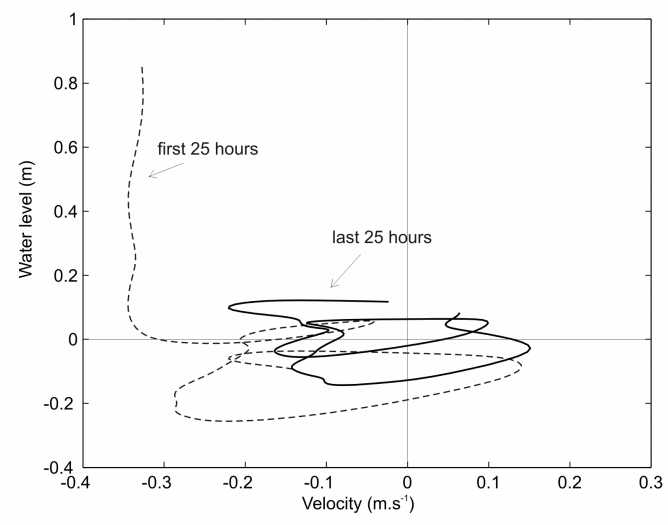

Fig. 7. Water level and current velocity diagram for first and last 25 hours of experiment.

\section{Conclusions}

The main findings of the short-term hydrographic experiment in the Araranguá estuary were:

1. the estuarine hydrodynamic structure responded rapidly to the flash-flood event;

2. the salt transport shifts from down-estuary dominated by river discharge to up-estuary dominated by gravitational circulation;

3. the low $\mathrm{pH}$ of estuarine waters and the low turbidity in the lower estuary suggest that the estuary acts as a source of dissolved pollutants for coastal waters, although it traps the fine sediments.

\section{ACKNOWLEDGMENTS}

The authors would like to express their thanks to the Defesa Civil, Corpo de Bombeiros and Yate Clube of Araranguá city for the logistic support and especially to Lt. Kemper, Sgt. Djalma Santos Niles and Sds. Sebastião A. de Souza and Geovanne Teixeira of the fire brigade of Araranguá city, as also to Mariana Couceiro and Marçal Duarte. The campaign was conducted with the support of the $\mathrm{CNPq}$ through the project: 'Processes of transport and retention of fine sediment in river dominated estuaries - TRANSEST' (CNPq: 306217/2007-4). Carla de Abreu D'Aquino has a CNPq PhD scholarship; CNPq Grant 306217/2007-4.

\section{REFERENCES}

ACHTERBERG, E. P.; HERZL, V. M. C.; BRAUGARDT, C. B.; MLLWARD, G. E. Metal behavior in an estuary polluted by acid mine drainage: the role of particulate matter. Environ. Pollut., v. 121, p. 283-292, 2003.

ALTHOFF, D. A. Irrigação do arroz: salinidade da água dos mananciais do sul de SC. Florianópolis: EMPASC, 1990. $24 \mathrm{p}$.

ANDRADE, M. C. Mineração e Meio Ambiente. ENESMA, V. 3, 1983, Florianópolis, p. 40-49.

ARAÚJO, C. E. S.; FRANCO, D.; MELO, E.; PIMENTA, F. 2003. Wave regime characteristics of southern brazilian coast. COPEDEC, 6., 2003. Proceedings... 2003. Paper n. 97,15 p. CD-ROM

BRAUNGARDT, C. B.; ACHTERBERG, E. P.; ELBAZPOULICHET, F.; MORLEY, N. M. Metal geochemistry in a mine-polluted estuarine system in Spain. Appl. Geochem., v. 18, p. 1757-1771, 2003.

BOWDEN, K. F. The mixing processes in a tidal estuary. J. Air Wat. Pollut., v. 7, p. 343-356, 1963.

CAMERON, W. N.; PRITCHARD, D. W. Estuaries. In: HILL, M. N. (Ed.). The sea. New York: Wiley Interscience, 1963. p. 306-332.

DYER, K. R. The salt balance in stratified estuaries. Estuar. coast. Mar. Sci.,v. 2, p. 273-281, 1974.

DYER, K. R. 1977. Lateral circulation effects in estuaries. In: Estuaries, geophysics and the environment. Washington, D.C.: National Academic Press, 1977. p.2229.

DYER, K. R. Sediment transport processes in estuaries. In: PERILLO, G. M. E. (Ed.). Geomorphology and sedimentology of estuaries. New York: Elsevier, 1995. p. 423-449.

DYER, K.R. Estuaries: A physical introduction $.2^{\text {nd }}$ Ed. New York: John Wiley and Sons, 1997. 195 p.

EPAGRI. Sistema de produção de arroz irrigado em Santa Catarina: (Pré-germinado). Florianópolis. 1998. 79 p. EPAGRI. Sistema de Produção, 32.

FISCHER, H. B. Mixing and dispersion in estuaries. A. Rev Fluid Mech., v. 8, p. 107-133, 1976.

GAIDIZINSKI, M. C. A rizipiscicultura no município de Meleiro. 114 p. 2001. Dissertação de Mestrado Departamento de Geociências, Universidade Federal de Santa Catarina, 2001. 
GAPLAN - GABINETE DE PLANEJAMENTO DE SANTA CATARINA. Atlas de Santa Catarina.Rio de Janeiro: Aerofoto Cruzeiro,.1986. $173 \mathrm{p}$.

GOTHE, C. A. V. Diagnóstico ambiental da região carbonífera Catarinense. ENESMA, V.3 Florianópolis, 1989. p. 62-96.

GOTHE, C. A. V. Avaliação dos impactos ambientais da indústria carbonífera nos recursos hídricos da região sul-catarinense. Florianópolis: Universidade Federal de Santa Catarina, 1993. UFSC. Dissertação de Mestrado em Geografia.

Hansen, D.V. \& Rattray, M. 1966 New dimensions on estuarine classification. Limnol. Oceanogr., v. 11, p. 319-326,

HILlE, E.; SCHETTINI, C. A. F.; RIBEIRO, M. R. Estrutura termohalina no litoral de Santa Catarina nos anos de 2005 e 2006. In: BRAGA, E. S. (Ed.). Oceanografia e mudanças globais. São Paulo: EDUSP, 2008. p. 371-382.

HUNKINS, K. Salt dispersion in the Hudson estuary. J. phys. Oceanogr., v. 11, p. 729-738, 1981.

KJERFVE, B. Circulation and salt flux in a well mixed estuary. In: KREEKE, VAN DE. (Ed). Physics of shallow estuaries and bays. New York: Spring-Verlag, 1986, p.22-29.

KREBES, A. S. J. Contribuição ao conhecimento dos recursos hídricos subterrâneos da bacia hidrográfica do rio Araranguá, SC. Tese de doutorado, 2004. Universidade Federal de Santa Catarina, 2004.

MEDEIROS, C.; KJERFVE, B. Longitudinal salt and sediment fluxes in a tropical estuary: Itamaracá, Brazil. J. coast. Res., v. 21, n. 4, p. 751-758, 2005.

MIRANDA, L. B. Propriedades e variáveis físicas das águas da plataforma continental do Rio Grande do Sul. Tese de Doutorado, 1972. São Paulo, Universidade de São Paulo, 1972.

MIRANDA, L. B.; CASTRO FILHO, B. M. On the salt transport in the Cananéia sea during a spring tide experiment. Rev. Bras. Oceanogr., v. 44, n. 2, p. 123133, 1996.

MIRANDA, L. B.; CASTRO, B. M.; KJERFVE, B. Princípios de Oceanografia Física de Estuários. São Paulo: Editora da Universidade de São Paulo, 2002. 424 p.

MÖLLER JR., O. O.; PIOLA, A. R.; FREITAS, A. C.; CAMPOS, E. J. D. The effects of river discharge and seasonal winds on the shelf off southeastern South America. Continent. Shelf Res., doi 10.1016/j.csr.2008.03.012.

NICHOLS, M. M.; BIGGS, R. B. 1985. Estuaries. In: DAVIS JR., R. A. (Ed). Coastal environments. sedimentary New York: Springer Verlag, p.77-186, 1985.

PEREIRA, M. D.; SCHETTINI, C. A. F.; OMACHI, C. Y. Caracterização de feições oceanográficas na plataforma de Santa Catarina através de imagens orbitais. Revta Bras. Geofís., v. 27, n. 1, p. 81-93, 2009.

PUGH, D. Tides, surges and mean sea level: a handbook for engineers and scientists. New York: John Wiley, 1987.

RÖRIG, L. R.; TUNDISI, J. G.; SCHETTINI, C. A. F.; PEREIRA FILHO, J.; MENEZES, J. T.; ALMEIDA, T. C. M.;URBAN, S. R.; RADETSKI, C. M.; SPERB, R. C.; STRAMOSK, C. A.; MACEDO, R. S.; CASTROSILVA, M. A.; PEREZ, J. A. A. From a water resource to a point pollution source: the daily journey of a coastal urban stream. Braz. J. Biol., v. 67, n. 1, p. 631-637, 2007.

SANTA CATARINA. Secretaria de Estado do Desenvolvimento Rural e da Agricultura. Zoneamento da disponibilidade e da qualidade hídrica da bacia do rio Araranguá. Florianópolis: 1997. Documento Síntese, v. 1.

SCHEIBE, L. F. 2002. O carvão em Santa Catarina: mineração e consequiências ambientais. Cadernos de Planejamento e Gestão Ambiental, n. 2, 2002. FEPAM. Porto Alegre/RS.

Schetini, C. A. F. Caracterização física do estuário do rio Itajaí-Açu. Rev. Bras. Rec. Hidric., v. 7, n. 1, p. 123-142, 2002a.

SCHETTINI C. A. F. Near bed sediment transport in the Itajaí-Açu River estuary, southern Brazil. In: WINTERWERP, J. C; KRANENBURG, C (Ed.). Fine sediment dynamics in the marine environment. New York: Elsevier, 2002b. p. 499-512.

SCHETTINI C.A.F. CARVALHO J. L.B., JABOR, P. Comparative hydrology and suspended matter distribution of four estuaries in Santa Catarina State, Southern Brazil. WORKSHOP ON COMPARATIVE STUDIES OF TEMPERATE COAST ESTUARIES, Bahia Blanca, 1996. Proceedings... 1996. p 29-32.

SCHETTINI, C. A. F.; CARVALHO, J. L. B. Hidrodinâmica e distribuição de sólidos em suspensão no estuário do rio Itajaí-açu (relatório). Notas Tec. Facimar, v. 2, p. 131-140, 1998.

SCHETTINI, C. A. F.; PEREIRA FILHO, J.; SPILLERE, L.C. Caracterização oceanográfica e biogeoquímica dos estuários dos Rios Tavares e Defuntos, Reserva Extrativista de Pirajubaé, Florianópolis, SC. Notas Téc. Facimar, v.4, p.11-28, 2000.

SCHETTINI, C. A. F; TOLDO JR, E. E. Fine sediment transport modes in the Itajaí-açu estuary, Southern Brazil. J. coast. Res., v. 39(SI), p. 515-519, 2006.

SCHETTINI, C. A. F.; RICKLEFS, K.; TRUCCOLO, E. C.; GOLBIG, V. Synoptic hydrography of a highly stratified estuary. Ocean Dynam., v. 56, n. 3-4, p. 308, 2006.

SIEGLE, E.; ASP, N. E. 2007. Wave refraction and longshore transport patterns along the southern Santa Catarina coast. Braz. J. Oceanogr., vol. 55, no. 2, p.109120, 2007.

TRUCCOLO, E. C.; FRANCO, D.; SCHETTINI, C. A.F. The low frequency sea level oscillations in the northern coast of Santa Catarina, Brazil. J. coast. Res., v. 39(SI), p. 547-552, 2006

VILLELA, R. Mineração de carvão em Santa Catarina e o meio ambiente. ENESMA, V. 3, 1989, Florianópolis, p $.50-61$.

WHITE, I., MELVILLE, M. D, WILSON, B. P.; SAMMUT, J. Reducing acidic discharges from wetlands in eastern Australia. Wetlands Ecol. Mgnts, v. 5, p. 5572, 1997.

(Manuscript received 09 December 2008; revised 04 April 2009; accepted 10 March 2010) 